PONTIFÍCIA UNIVERSIDADE CATÓLICA DO RIO DE JANEIRO

\title{
A Análise da Ativação de Marcas em Eventos de Hospitalidade
}

Luiz Gabriel Nouh Chaia de Almeida

Trabalho de Conclusão de Curso

Centro de CIÊNCIAS SOCIAIS - CCS

DEPARTAMENTO DE AdMINISTRAÇÃO

Graduação em Administração de Empresas 


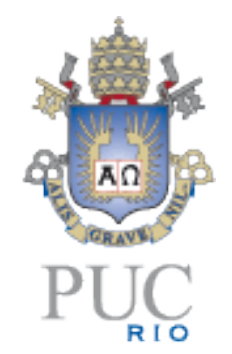

Luiz Gabriel Nouh Chaia de Almeida

\section{A Análise da Ativação de Marcas em Eventos de Hospitalidade}

Trabalho de Conclusão de Curso

Trabalho de Conclusão de Curso, apresentado ao programa de graduação em Administração da PUC-Rio como requisito parcial para a obtenção do título de graduação em Administração.

Orientadora: Marcela Amorim

Rio de Janeiro Dezembro de 2016. 


\section{Agradecimentos}

Gostaria de dedicar esse trabalho à minha mãe que me criou com muito carinho e fez questão de me educar até eu me tornar quem sou hoje. Sou muito grato ao meu pai e ao meu padrasto pelos ensinamentos e oportunidades que eles me proporcionaram.

Agradecimentos especiais ao meu irmão de sangue Cadu e meus irmãos de consideração lan, Caio e Barriga, por estarem sempre ao meu lado. 


\section{Resumo}

De Almeida, Luiz. Ativação de Marcas no Setor de Hospitality O caso Tropicalisto. Rio de Janeiro, 2016. Número de páginas p. Trabalho de Conclusão de Curso - Departamento de Administração. Pontifícia Universidade Católica do Rio de Janeiro.

O investimento em estratégias de comunicação não tradicionais, ainda pouco explorado na literatura, está se tornando cada vez mais frequente nas organizações que querem se comunicar com seu público de maneira eficaz e com baixo custo. Portanto, torna-se importante a compreensão dos desdobramentos de tais estudos na perspectiva do consumidor.

Este trabalho apresenta um estudo de caso de uma estratégia de comunicação não tradicional, na forma de patrocínio de eventos de hospitalidade. Após a identificação de dificuldades, o objetivo é apontar alguns aspectos perceptivos dos frequentadores de eventos semelhante ao do caso e sugerir ações para mitigar essas dificuldades.

A pesquisa qualitativa é baseada nas experiências dos frequentadores das Casa Olímpicas durante as Olímpiadas 2016 no Rio de Janeiro.

Verificou-se que a percepção do público, em resposta às experiências e ações de marca dentro dos eventos de hospitalidade, é muito diversa e de difícil mensuração.

Os resultados da pesquisa exploratória indicam que esse tipo de estratégia não deve atingir somente dimensões sensoriais, afetivas e comportamentais para que a marca atinja os objetivos pretendidos e fique na memória do consumidor.

Palavras- chave

Comunicação Below the Line, Marca, Branding, Hospitality, Experiência, Percepção, Patrocínio 


\section{Abstract}

De Almeida, Luiz. Brand Activation in the Hospitality Industry, the Tropicalisto case. Rio de Janeiro, 2016. Número de páginas p. Trabalho de Conclusão de Curso - Departamento de Administração. Pontifícia Universidade Católica do Rio de Janeiro.

Investing in non traditional communication strategies, little explored in the literature still, is becoming more and more frequent in organizations that want to communicate effectively and inexpensively to their audiences. Therefore, becomes important to understand the unfolding of such studies from the perspective of the consumer.

This paper presents a case study of a non-traditional communication strategy in the form of sponsorship of hospitality events. After identifying difficulties, the objective is to point out some perceptive aspects of event attendees similar to the case and suggest actions to mitigate these difficulties.

The qualitative research is based on the experiences of the Olympic House goers during the 2016 Olympics in Rio de Janeiro.

It was found that public perception, in response to brand experiences and actions within hospitality events, is very diverse and difficult to measure.

The results of the exploratory research indicates that this type of strategy should not only reach sensory, affective and behavioral dimensions in order to the brand achieve the objectives and remains in the consumer's memory.

Key-words

Below the Line Communication, Brand, Branding, Hospitality, Experience, Perception, Sponsoring 


\section{Sumário}

1 Introdução 1

2 Revisão da Literatura 6

2.1. Marca 6

2.1.1. Branding 8

2.2. Patrocínio 9

2.2.1. Formas de Patrocínio de Eventos 12

2.2.1.1. Experiência de Marca 12

2.2.1.2. Ativações de Marca 13

$\begin{array}{ll}\text { 2.2.1.3. Hospitalidade } & 15\end{array}$

3 Metodologia de pesquisa 16

3.1. O caso da Tropicalisto 16

3.1.1. Entrevista com a CEO da empresa 18

4 Resultados 21

$\begin{array}{ll}\text { 4.1. Entrevistas } & 21\end{array}$

5 Conclusões $\quad 28$

6 Referências $\quad 30$ 


\section{Lista de figuras}

Figura 2: Caixa patrocinadora do Flamengo............................................... 10

Figura 3: Patrocinadores dos times Vasco e Fluminense................................... 10

Figura 4: Tirolesa da Heineken durante o Rock in Rio sobre o público na direção de um totem gigante da cerveja da marca..............................................15 


\section{Introdução}

Este trabalho aborda um tema emergente conhecido como patrocínio de eventos de hospitalidade. Ao trazer casos que aconteceram durante a Copa do Mundo 2014 e as Olimpíadas 2016, o objetivo é contribuir para uma melhor compreensão da importância do patrocínio de eventos como ferramenta na gestão de marcas.

Muitos executivos e empreendedores se perguntam como irão atrair, engajar e se destacar dos demais em um cenário de constante mudança e alta competitividade. O marketing pode ser considerado um ponto de contato que uma empresa tem com qualquer pessoa no ambiente externo, tendo por vezes, o poder de levar os potenciais consumidores ao comportamento de compra. Isto é, cada ação que a empresa realizar irá afetar a percepção das pessoas em relação a ela mesma (Levinson, 2007). O marketing é um processo evolutivo, considerando que as corporações terão que crescer e se transformar de forma a se adaptarem ao meio no qual estão inseridas. Esse, por sua vez, está em constante mudança.

De acordo com dados da pesquisa realizada em 2010, pelo SENAC, o mercado publicitário mundial e brasileiro está mudando o foco dos investimentos, substituindo as mídias tradicionais por outras ferramentas de comunicação mais eficazes e segmentadas. Alguns exemplos como marketing direto, mídias sociais, internet, marketing viral ${ }^{1}$ e merchandising ${ }^{2}$ estão sendo usados como estratégias promocionais.

Para obter vantagem competitiva e conseguir alcançar melhor performance não só no âmbito do marketing de acordo com a Escola do Posicionamento, as empresas devem estar atentas a tudo que se encontra à sua volta, ou seja, devem levar em consideração fatores estruturais e os papéis de cada ator na arena competitiva como concorrentes, fornecedores, consumidores, novos entrantes e substitutos; macro forças ambientais econômicas, políticas,

\footnotetext{
1 Marketing viral ou publicidade viral referem-se a técnicas de marketing que tentam explorar redes sociais pré-existentes para produzir aumentos exponenciais em conhecimento de marca, com processos similares à extensão de uma epidemia.

${ }^{2}$ Merchandising é citação ou aparição de determinada marca, produto ou serviço, sem as características explícitas de anúncio publicitário, em programa de televisão ou de rádio, espetáculo teatral ou cinematográfico etc.
} 
tecnológicas, socioculturais e demográficas, assim como inovações e tendências. Devem considerar também, segundo a Escola Baseada em Recursos, os recursos internos tangíveis e intangíveis como diferenciais para alcançar os objetivos traçados pela estratégia. Em outras palavras as companhias devem usar o trunfo dos recursos internos para implementar a estratégia e conseguir mitigar possíveis ameaças e explorar oportunidades. (Macedo-Soares, 2009)

Segundo a Ampro - Associação Brasileira de Marketing Promocional - a publicidade representa uma verba de 9.9 bilhões de reais, ou seja, $43 \%$ do total dos investimentos em comunicação e marketing, conforme levantamento realizado pela entidade e apresentado no I EBEMP ${ }^{3}$ em 2010. Hoje, em 2016, é estimado que este valor já ultrapasse os 15 bilhões de reais.

A globalização e a abertura dos mercados socialistas no período pós guerra fria, contribuíram para a concorrência em nível global. Essa dinâmica competitiva afeta as empresas com nível alto de maturidade e principalmente as mais novas como as startups ${ }^{4}$.

No século $X X$, as empresas se importavam mais com os produtos que vendiam e a máxima capacidade produtiva, passando, posteriormente, a se preocupar com as técnicas de vendas. Alguns anos depois, considerou-se que havia falta de orientação para o cliente e que a criação de valor era mais importante do que somente o foco na elaboração de um produto. Foi ai que o marketing diferenciado e segmentado surgiu. O conceito de relacionamento duradouro com o cliente começou a ganhar importância quando as técnicas de vendas já não eram mais eficientes e não tinham mais força junto aos consumidores mais exigentes. O marketing promocional e a valorização das marcas tem sido fundamentais para que a constante inovação seja posta em evidência na relação entre empresa e consumidor. O século XXI chegou trazendo a revolução digital e a globalização. A tecnologia possibilitou o encurtamento da cadeia de valor para as empresas que hoje conseguem entregar um serviço complexo e diferenciado. Nesse cenário altamente competitivo, o desenvolvimento da publicidade e da promoção de vendas, tomou uma nova forma e surgiram dois novos conceitos: Above The Line (ATL) e Below The Line (BTL) communication (Aditya, 2009).

${ }_{4}^{3}$ Encontro Brasileiro das Empresas de Marketing Promocional

4 startup é uma empresa recém criada, ainda em fase de desenvolvimento e pesquisa de mercados. O termo tornou-se popular internacionalmente durante a bolha da internet, quando um grande número de "empresas.com" foram fundadas. 
A comunicação ATL é um tipo de comunicação veiculada pelos canais tradicionais de marketing que pretendem atingir um público de massas, através de uma mensagem que reforça a comunicação sobre um produto ou que estimule a reação emocional do receptor da informação. Assim, a ATL foca no alcance em massa, criando uma sensibilização da marca, na qual o consumidor não se envolve diretamente. A rádio, a televisão, as revistas, os outdoors e os jornais são exemplos desse tipo de comunicação. Já a comunicação Below The Line foca no consumidor, originando uma experiência com envolvimento direto do potencial cliente. Eventos, marketing de relacionamento, interação por parte dos consumidores, as exposições, os patrocínios, licenciamentos, promoções, as relações públicas, os descontos comerciais e vales de compras são exemplos deste tipo de comunicação.

As primeiras aparições dessas terminologias surgiram quando publicitários e profissionais de marketing começaram a apresentar os orçamentos de promoção em uma representação gráfica separada por uma linha, destacando em cima as despesas com mídias e embaixo as despesas sem ser com mídia. (Baynast \& Emprin, 2008).

Schmitt (2000) defende que o Marketing Tradicional está ultrapassado e que as empresas precisam, urgentemente, de se concentrar em estratégias de Marketing Experiencial, pois a diferenciação através dos benefícios funcionais dos seus produtos não dura eternamente. Nos últimos anos, diversos autores como Keller e Aaker, apresentam a construção de marcas fortes como fator diferenciador. Estas marcas devem ser capazes de gerar interesse e emoções nos indivíduos. Marcas que emocionam, que desenvolvem relacionamentos com os seus consumidores garantem uma diferenciação única nos mercados onde se inserem, trabalhando em um nível intangível difícil de ser igualado. Por outro lado, os consumidores querem algo além da funcionalidade dos produtos, desejam experiências que os surpreenda, que abranjam todas as dimensões de uma experiência (sensorial, afetiva, intelectual e comportamental) (Brakus, Schmitt e Zarantonello (2009).

Segundo estudos feitos pelo Winterberry Group (PR Newswire, 2007), as principais tendências que afetam a mudança nos orçamentos de marketing nas empresas, optando pelo BTL ao invés do ATL, são as seguintes: 
- O crescimento do nível de exigência dos consumidores tem aumentado a procura de informação através de canais de comunicação alternativos.

- A diminuição do impacto das mensagens publicitarias, que não são dirigidas especificamente às necessidades dos consumidores.

- Os avanços tecnológicos permitem interações constantes entre empresa e consumidor, mais fáceis e mais relevantes do que anteriormente.

- As mudanças macro-ambientais demográficas dos consumidores fazem diminuir a influência das mensagens de marketing tradicional através das mensagens de massa.

- A eficiência das campanhas híbridas, isto é, campanhas que passam por diferentes tipos de canais de comunicação, reforçam relações diretas entre profissionais de marketing e consumidores.

A partir do momento que os meios de comunicação Below The Line (BTL) começaram a atender às demandas esperadas, esta nova forma de promoção começou a prosperar. Esta abordagem passou a ser uma forma de interação com os produtos e serviços, ou seja, o consumidor tem acesso imediato à informação que precisa. Isso faz com que o consumidor conheça a marca, lembre dela, a reconheça e as associe com as características do produto/serviço.

Com a chegada da crise em diferentes países, as despesas de marketing eram vistas mais como gastos do que como investimentos. Isso possibilitou que a comunicação BTL passasse a ter mais relevância nas organizações, visto que as despesas são menores do que outro tipo de comunicação e a eficácia é alta. Com o tempo, a capacidade única de personalização da comunicação BTL está se mostrando capaz de substituir a publicidade e caminha para se tornar um veículo de massas. Hoje, os esforços BTL conseguem ser mensurados em relação à performance de cada campanha. Esse fator realça a importância do marketing estratégico nas empresas não só para desenvolvimento de uma marca, mas sim em nível global.

O problema de pesquisa deste trabalho surgiu a partir de uma entrevista com Andrea Carel, a CEO da empresa Tropicalisto, sobre um caso de evento de hospitalidade, no qual o conceito será descrito ao longo da realidade 
investigada. Tal objetivo era descrever as diferentes formas de ativação dentro de ações de patrocínio de eventos de hospitalidade.

Dentre os tipos de comunicação BTL, serão citadas na seção seguinte as diferentes formas de patrocínio e suas implicações no mercado. Posteriormente, um caso será analisado abordando o tema central do trabalho sobre um tipo específico de patrocínio. 


\section{Revisão da Literatura}

Neste capítulo são apresentados e discutidos aspectos conceituais e estudos relacionados ao tema em investigação e que servirão de base para a análise realizada.

Esta seção está dividida em três partes e abordam, respectivamente, a questão de marca e branding, para contextualizar o problema de estudo sobre como a valorização da marca no ambiente competitivo é um diferencial para as empresas, a percepção das pessoas e o conceito de patrocínio segundo diferentes autores, seus tipos e objetivos. Na continuação, são apresentadas as formas de patrocínio segundo uma categoria específica.

\subsection{Marca}

Como objetivo básico, as empresas buscam atender as necessidades de um grupo de consumidores. Desse modo, essas oferecem "de maneira constante e repetida, a combinação ideal de atributos tangíveis e intangíveis, funcionais e hedonistas, visíveis e invisíveis em condições economicamente viáveis para ela" (Kapferer, 2004, p.40).

No processo da compra, o consumidor procura o bem ou serviço que se aplique às conformidades esperadas ou imaginadas por ele e, assim, planeja a tomada de decisão de compra. Outro elemento decisivo nesse processo é a existência, ou inexistência, de uma marca e sua capacidade de influenciar a mente dos consumidores.

Segundo Aaker (1998), uma marca é:

Um nome diferenciado e/ou símbolo (tal como logotipo, marca registrada, ou desenho de embalagem) destinado a identificar os bens ou serviços de um vendedor ou de um grupo de vendedores e a diferenciar esses bens e serviços daqueles concorrentes.

$\mathrm{Na}$ atualidade do mercado, altamente competitivo, as marcas têm se mostrado mais importantes no que abrange a diferenciação entre empresas. Muitas das vezes sendo responsável pelo sucesso de um produto ou serviço junto aos consumidores. 
A marca acrescenta dimensões que diferenciam outros produtos destinados a satisfazer a mesma necessidade. Tais diferenças podem ser racionais e tangíveis relacionadas com o desempenho do produto da marca ou mais simbólicas, emocionais e intangíveis - relacionadas com o que a marca representa.

Pode-se entender de várias formas o sentido de o que é uma marca. $\mathrm{O}$ estudo feito por Chernatony e Dall'Olmo Riley (1998) identifica diferentes interpretações:

- Instrumento Legal - Marca como um investimento. Indica posse e proteção.

- Logotipo - Marca como identificação visual (nome, símbolo, sinais, design).

- Empresa - Marca como visão global coerente do portfólio da marca para todos os stakeholders ${ }^{5}$.

- Estenografia - Marca como um sistema de alertas, facilita as decisões e o reconhecimento.

- Redução de Risco - Marca como um fator de confiança.

- Sistema de Identidade - Marca referida à estratégia com uma visão integrada e consistente, sendo mais do que a soma das partes.

- Imagem - Marca como transmissora de atributos funcionais e psicológicos para o consumidor

- Sistema de Valores - Marca como transmissora de valores, com os quais o consumidor identifica.

- Personalidade - Além dos valores funcionais existem valores humanos e sociais, difundidos através da comunicação da marca.

- Relacionamento - A marca é humanizada então o consumidor poderá estabelecer uma relação com ela.

- Valor Agregado - Marca como meio para obter uma vantagem competitiva.

${ }^{5}$ Stakeholder significa público estratégico e descreve uma pessoa ou grupo que fez um investimento ou tem ações ou interesse em uma empresa, negócio ou indústria. 
Ao ler essas interpretações, fica claro o posicionamento dos autores de que as marcas são extensões do produto, serviço e da própria empresa.

Existem atributos acerca das características tangíveis do produto como o nome, embalagem, serviços, garantias ou a qualidade que representam as bases da diferenciação no âmbito da vantagem competitiva. Com o entendimento do que é marca, se faz necessário o desenvolvimento do tema em relação ao seu gerenciamento.

\subsubsection{Branding}

Pavitt (2003) explica que "branding é principalmente o processo de afixar um nome e uma reputação para algo ou alguém”. Esta conceituação leva a uma forma simples de identificar e distinguir.

Pinho (1996) descreve que "a marca é a síntese dos elementos físicos, racionais, emocionais, e estéticos nela presentes e desenvolvidos através dos tempos". Entende-se que a marca vem sendo utilizada através dos tempos com a intenção de identificar e distinguir um produto ou serviços dos concorrentes. Porém, as marcas passaram a desempenhar papéis mais complexos, e, com isso, houve a necessidade de um processo de gestão que favorecesse o reconhecimento e a fidelidade da marca por parte dos clientes.

Para Guimarães (2003, p. 87) "o branding é uma filosofia de gestão de marca, ou seja, uma maneira de agir e pensar sobre uma determinada marca". Para Guimarães, a gestão de marca vai além do design puro, envolve outras áreas de conhecimento, como o marketing, que busca através de ações interdisciplinares, gerenciar os diversos discursos da marca.

O branding tem a função de gerenciar os diversos discursos de uma marca, que são oriundos de várias áreas do conhecimento, buscando unidade nas manifestações de identidade da marca. O marketing entra com sua função de planejamento, pesquisa de informações estratégicas para a idealização do produto. O design tem a função de decodificar essas informações, e, através delas, expressar visualmente a marca (RODRIGUES, 2006). A propaganda tem a missão de divulgar a personalidade da marca e gerar conhecimento. A arquitetura é um forte elemento de experiência, tanto do ponto de venda, quanto no contato com os colaboradores e funcionários da empresa. A administração e suas subáreas têm a função de planejar, organizar, gerenciar e controlar o trabalho de seus funcionários e colaboradores. 
Dessa forma, entende-se que o branding pode ser considerado um sistema de ações interdisciplinares que visa o estabelecimento de imagens, percepções e associações com as quais o consumidor se relaciona com um produto ou empresa. Assim, o branding é a construção e a gestão da marca através de todos os pontos de contato vivenciados pelo usuário.

\subsection{Patrocínio}

Segundo POZZI (1998) as pesquisas sobre patrocínio têm início em meados da década de 80 , tendo grande crescimento no começo dos anos 90 , o que denota que o conhecimento sobre o assunto é recente.

Patrocínios esportivos, culturais e sociais estão presentes no ambiente competitivo das grandes corporações na disputa pelos seus mercados, embora também sejam encontrados nas ações de marketing das pequenas e médias empresas.

No contexto atual, produtos e serviços de qualidade, preço competitivo, e diferencial tecnológico não asseguram mais o sucesso empresarial e a marca surge como fator diferencial. Se tratando de um dos maiores patrimônios da organização, a marca se tornou o fator preponderante na comunicação e no marketing estratégico de qualquer empresa.

Ainda para POZZI (1998) o patrocínio é "a provisão de recursos financeiros, humanos ou físicos por uma organização diretamente para um evento ou atividade em troca de uma associação direta com o mesmo".

Hoje em dia é significante o número de empresas que atuam como patrocinadores sócio culturais, do esporte e do entretenimento como fator de alavancagem das suas ações. Com isso, o patrocínio acabou se tornando o elo entre o mix de marketing e o composto promocional da organização. 


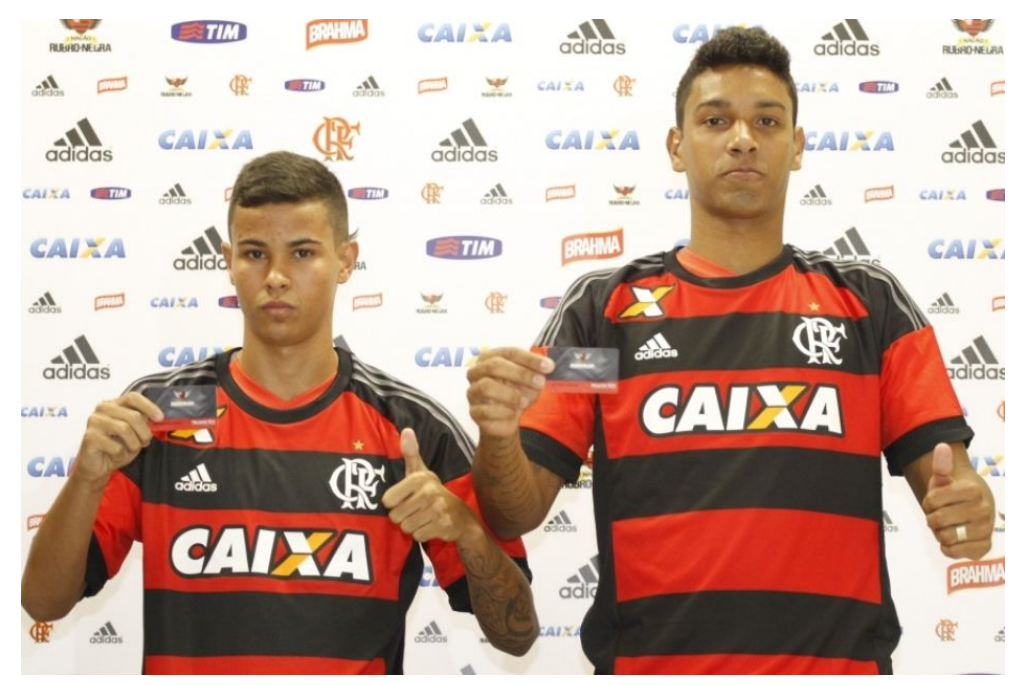

Figura 2: Caixa patrocinadora do Flamengo.

FONTE:http://esporte.band.uol.com.br/futebol/times/flamengo/noticias/?id= 100000790365\&t=flamengo-tem-o-maior-patroc\%C3\%ADnio-da-caixa

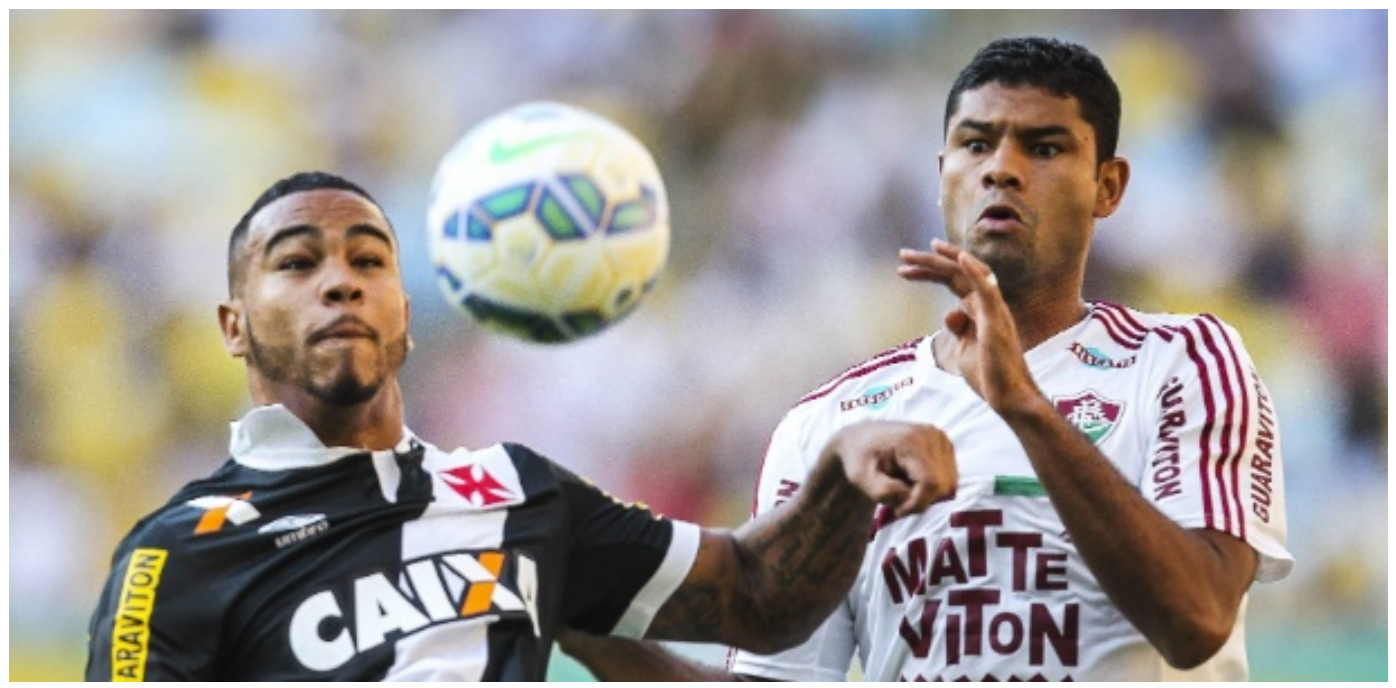

Figura 3: Patrocinadores dos times Vasco e Fluminense.

FONTE: http://esporte.uol.com.br/futebol/ultimas-noticias/2016/01/04/aposfla-caixa-negocia-com-flu-e-vasco-e-pode-pagar-r-60-mi-a-cariocas.htm

Porém, Pozzi conceitua o patrocínio apenas sob o enfoque operacional e, diante disso, é necessário abordar mais profundamente a questão, pois o patrocínio evoluiu para uma dimensão mais ampla de natureza estratégica, conforme se observa na definição de Melo Neto (2003): 
"É uma ação de marketing promocional que, ao dar suporte às demais ações do composto promocional contribui para o alcance dos objetivos estratégicos de marketing da empresa, em especial no que se refere à imagem corporativa, promoção da marca, posicionamento do produto, promoção de vendas e comunicação com clientes, fornecedores, distribuidores e demais parceiros".

No contexto do Marketing Estratégico a importância do patrocínio é tal que alguns autores já falam em "mix de patrocínio", o qual envolve ações de prospecção e identificação dos alvos do patrocínio, o valor do investimento, os locais de realização das ações de patrocínio e as ações de comunicação desse.

A definição que mais se adequa a este presente trabalho é a de Sandler e Shani (1989) em sua pesquisa sobre a eficiência do patrocínio:

"Patrocínio é a atividade de provisão de recursos (dinheiro,
pessoas, equipamentos) por uma organização diretamente
para um evento ou atividade em troca da direta associação
com esse evento ou atividade. A organização provedora dos
recursos então usa essa associação direta para alcançar seus
objetivos corporativos, de marketing, ou mídia".

Para os autores, não existe uma só definição sobre patrocínio. As definições normalmente refletem a visão especifica que cada organização considera preferível.

O patrocínio é, portanto, uma relação de troca entre a marca patrocinadora e o patrocinado com uma relação que pode beneficiar ambas as partes. $O$ ato de patrocinar pode ser conceituado como a realização de um investimento de marketing onde se busca estabelecer uma associação positiva entre a imagem, a marca e o produto ou serviço da empresa, através de diversas estratégias.

Melo Neto (2003) divide o patrocínio em quatro categorias: o cultural, social, esportivo e ecológico. Por outro lado, Shimp (2002) divide em apenas dois grupos, o patrocínio de eventos e o relacionado a causas.

Todos esses tipos mencionados são relevantes, porém o foco deste trabalho será no patrocínio de eventos. Através da descrição do caso de uma empresa que atua no setor de Entretenimento e Hospitalidade carioca, foi levantado um problema para investigação e análise do tema.

Dentre os diversos objetivos do patrocínio, segundo Meenaghan (1983), os que mais ganham destaque para esse trabalho são os de hospitalidade para convidados e cobertura de mídia. Conforme seus estudos, o patrocínio de atividades e eventos permite que as empresas patrocinadoras utilizem a praça como um centro de hospitalidade para convidados, num ambiente apropriadamente informal. Esses locais permitem a interação direta entre executivos e seus principais clientes, potenciais clientes, formadores de opinião e líderes governamentais. Já a cobertura de mídia de eventos sempre assumiu 
um dos papéis mais importantes no programa de patrocínio. As empresas de álcool e tabaco, por exemplo, pioneiras nesse tipo de comunicação, driblavam as restrições de propagandas de suas marcas.

A popularização e exposição de eventos culturais e esportivos na mídia também foi um fator determinante para o investimento em patrocínio (Meenaghan, 1983), em comparação às outras formas de comunicação ATL.

\subsubsection{Formas de Patrocínio de Eventos}

Oliveira e Pozzi (1996) afirmam que o maior benefício oferecido pelo patrocínio é transferir a emoção do evento para a marca do patrocinador. Segundo seus estudos, o objetivo do patrocínio de eventos é reforçar a imagem da marca e estabelecer identificação com o público alvo através de emoções e sentimentos. Apesar da lacuna que existe na literatura sobre o tema, serão descritos nessa subseção alguns dos tipos de patrocínio usados em eventos.

\subsubsection{Experiência de Marca}

Brakus et al (2009) afirmam que os consumidores estão expostos aos atributos utilitários dos produtos quando se encontram nas fases de procura, compra e consumo de marcas. No entanto, e apesar de ser uma área ainda não estudada pela maioria dos pesquisadores, que se focam sobretudo na experiência de consumo, os autores defendem a existência de experiências de marca. Desta forma, os autores conceituam experiência de marca como sendo respostas internas dos consumidores, em forma de sensações, sentimentos, respostas cognitivas e respostas comportamentais, que surgem como reação a um estimulo da marca, que pode ser encontrado na identidade da marca, na embalagem e comunicação e/ou no ambiente em que a marca é comercializada.

Segundo Pine e Gilmore (1998), as experiências sempre fizeram parte do coração do setor de entretenimento e as novas tecnologias possibilitaram uma ampla diversidade do gênero. "Hoje o conceito de vender experiências está se espalhando além dos teatros e parques temáticos".

A experiência de marca pode variar em força e intensidade, pois algumas experiências podem ser mais intensas do que outras, pode variar na avaliação, pois dependem da subjetividade do usuário, e, por último, variar em tempo de duração. Podem ser experiências que ocorrem espontaneamente, sem exigir 
grande reflexão e duram durante pouco tempo, enquanto acabam por ter uma duração maior, podendo ficar instaladas na memória do consumidor.

Apesar de ser conceitualmente semelhante a outros conceitos de marca, a experiência é nomeada em relação a atitudes perante a marca, envolvimento, ligação, personalidade e encanto/satisfação do consumidor.

Fishbein e Ajzen (2009) referem-se a atitudes como sendo avaliações gerais que surgem com base em crenças ou reações afetivas automáticas. Pelo contrário, Brakus et al (2009) conceituam experiência de marca não como um julgamento generalista acerca da marca, mas como sensações, sentimentos, respostas cognitivas e respostas comportamentais como resultado de um estimulo emitido pela marca. Nesse sentido, defendem que a atitude frente a marca apenas representa uma pequena parte da experiência de marca total.

A ligação com a marca é uma construção emocional, que pode ser entendido como um vínculo entre o consumidor e uma marca. Os autores argumentam que experiência de marca é algo mais amplo do que a ligação com a marca, visto que as emoções são apenas uma parte do resultado de toda a experiência.

A experiência não acontece apenas depois do consumo, mas sim quando uma interação ocorre com a marca, seja de forma direta ou indireta, sem necessidade de ser surpreendente. Assim, os autores diferenciam a construção da experiência de marca do encantamento/satisfação do consumidor, pois segundo Oliver (1997) o encanto do consumidor pode ser considerado como sendo o componente afetivo da satisfação, pelo que só se verifica após o consumo.

\subsubsection{Ativações de Marca}

Por ser um conceito relativamente recente e em constante transformação, definir ativação de marca é uma tarefa complexa. Organizações do setor de hospitalidade e entretenimento utilizam as ativações de marcas, na maioria das vezes marcantes e com caráter inovador, para encantar o público alvo. As ativações enriquecem a experiência da marca de forma holística, pois através de estímulos relacionados à marca, logo, símbolos, slogan e personagens, o consumidor consegue vivenciar a experiência memorável através de sensações, sentimentos e respostas comportamentais.

Kapferer (1991) explica que a marca depende de sua comunicação para ser conhecida e reconhecida. Ao desenvolver uma estratégia de comunicação, 
deve-se escolher os canais mais adequados para o efeito pretendido se concretizar. Assim, Aaker (1996) afirma que sem consonância com os valores da marca e uma estratégia minimamente estruturada, os objetivos da ação planeada não vão ser alcançados. Logo, para que uma estratégia de comunicação seja bem-sucedida, é fundamental identificar o público com que se pretende comunicar de forma clara e concisa. Ainda para Kapferer (2000) as empresas procuram um maior envolvimento dos consumidores e dão a entender que estes fazem parte delas. A realização de ativações de marca possibilita que isso aconteça.

Apesar do conceito ser relativamente recente, é uma ferramenta que permite a interação com o público. O objetivo da ativação de marca é oferecer uma experiência real ao consumidor, de modo que uma conexão seja estabelecida com os mesmos.

Empresas como Heineken e Red Bull utilizam essa estratégia de conexão como parte da comunicação de marketing. Elas patrocinam diversos eventos e promovem ativações nos locais, como por exemplo a ativação da Heineken no Rock in Rio.

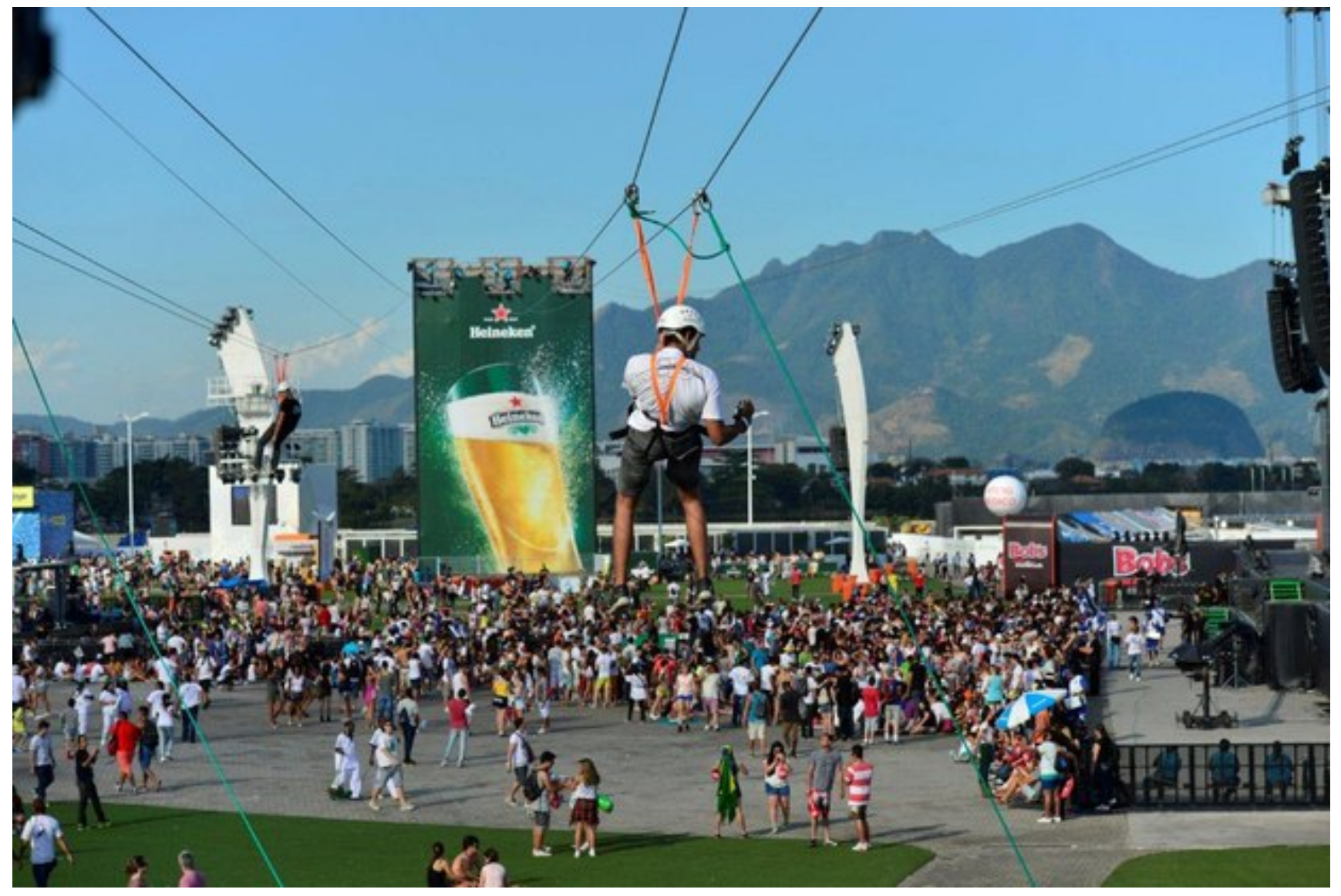


Figura 4: Tirolesa da Heineken durante o Rock in Rio sobre o público na direção de um totem gigante da cerveja da marca.

FONTE: http://odia.ig.com.br/diversao/2013-09-15/rock-in-rio-jovemparaplegico-anda-de-tirolesa-e-se-emociona.html

\subsubsection{Hospitalidade}

Cruz (2002) afirma que hospitalidade é um fenômeno muito mais amplo do que definições feitas por demais autores. Não se restringe somente à oferta de abrigo e alimentos aos consumidores.

A hospitalidade no formato de eventos pode ser apresentada de diversas formas e com associações distintas tais quais: conforto, receptividade, sociabilidade, alimentação, lazer entre outras. Não tendo uma forma e conceito único, levando em consideração variações de tempo e lugar.

O que se pode ter certeza é que independente do tempo e do espaço, o fenômeno da hospitalidade visa o bem-estar e a satisfação do visitante que será alcançado através de um processo perceptivo e subjetivo individual. 


\section{Metodologia de pesquisa}

Nesta parte será feita uma análise interpretativa com três fontes de evidencia: Dados secundários da empresa obtidos através de arquivos internos, entrevista com a CEO e entrevistas com um grupo de sujeitos de 15 integrantes que frequentaram ou trabalharam nas casa olímpicas, no Rio de Janeiro.

Para investigar a situação problema, foi feita uma pesquisa qualitativa através de entrevistas com uma amostra de 15 pessoas que frequentaram ou trabalharam nas casas olímpicas durante as Olimpíadas 2016, sediadas no Rio de Janeiro. Para efeito de análise e comparação, a amostra entrevistada foi segmentada por idade (de 22 a 30 anos) e por renda (classe média-alta), em razão dos altos preços de entrada (quando paga), alimentação e bar.

Por conta do tema ser pouco desenvolvido na literatura, a pesquisa foi de cunho exploratório para identificar percepções e associações do público que frequentou as casas de hospitalidade olímpicas. Segundo Gil (2008):

"As pesquisas exploratórias têm como principal finalidade desenvolver, esclarecer e modificar conceitos e ideias, tendo em vista a formulação de problemas mais precisos ou hipóteses pesquisáveis para estudos posteriores. Este tipo de pesquisa é realizado especialmente quando o tema escolhido é pouco explorado, podendo ou não formular hipóteses".

\section{1. $O$ caso da Tropicalisto}

A Tropicalisto é uma agência criativa britânica-brasileira de pequeno porte, fundada em 2013, que desenvolve estratégias de ativação e engajamento para marcas que atuam no mercado de hospitalidade através de eventos, conteúdo de marca, campanhas de imprensa e estratégias digitais.

A empresa surgiu com uma sociedade entre Andrea Carel, sueca graduada em branding, e a jornalista Lauren Holmes. Ambas com experiência no mercado europeu e vasto networking no setor de hospitalidade. 
Dentro de seu escopo e junto aos seus colaboradores, a empresa atua como fornecedora de:

- Consultoria de hospitalidade

- Serviço de concierge

- Curadoria de eventos

- Comunicação e estratégia digital

- Desenvolvimento de conteúdo

- Engajamento

Depois de 10 anos de experiência trabalhando no setor de hospitalidade, eventos e branding global, as fundadoras da Tropicalisto perceberam uma lacuna no mercado em comparação à Europa e aos EUA. Durante a Copa do Mundo de 2014 sediada no Rio de Janeiro, com a intenção de aproveitar esse fator como uma oportunidade, a Tropicalisto promoveu em parceria com o restaurante The Fat Radish, de Nova York, e com a marca de bebidas Absolut Elyx para produzir uma experiência de luxo na Copa: A Casa Fat Radish.

Durante a Copa do Mundo de 2014, Tropicalisto concebeu e produziu a Casa Fat Radish, no formato pop-up (de curta temporada). O evento de um mês de duração combinou um bar de coquetéis, um restaurante gourmet, sala de projeção e piscina com uma série de atividades e festas. A experiência foi criada para apresentar o melhor do Rio de Janeiro para um público internacional de luxo, unindo os principais talentos do design, da arte e da gastronomia em um local sofisticado.

O conceito do projeto era aproveitar a oportunidade da Copa para mostrar o melhor dos talentos nacionais, a cultura contemporânea e as origens brasileiras para o público internacional. Ao invés das praias estereotipadas, samba e caipirinha, os convidados foram ao encontro do design, arquitetura clássica de uma mansão em Santa Teresa e novos artistas se apresentando ao vivo nos intervalos dos jogos. A proposta era criar uma experiência completa sem exposição excessiva de marca.

O público alvo teve acesso livre para frequentar os eventos, participar dos jantares e convidar um(a) acompanhante. Nomes como Gerard Butler, Jamie Oliver e a seleção alemã visitaram a casa. O resultado dessa iniciativa foi a repercussão da experiência pelas mídias sociais e o engajamento do público 
alvo. A entrada, mediante reserva por telefone ou e-mail, custava $R \$ 250,00$ para passar o dia na casa e $\mathrm{R} \$ 350,00$ para o jantar, incluindo cinco pratos.

Além das parcerias com as grandes marcas, a Tropicalisto contou também com a participação da Fundação Gastromotiva, que atua como programa de impacto social em quatro cidades brasileiras através de cursos de culinária para população de baixa renda. Os estudantes da Gastromotiva foram contratados para trabalhar com os chefs internacionais do Fat Radish e o evento arrecadou doações de RS80.000,00 para a fundação.

O envolvimento com as marcas e a comunicação da ativação foi um sucesso, pois ao longo de cinco semanas, 7850 pessoas frequentaram a casa e aproximadamente 3500 interagiram com as mídias sociais. O impacto de mídia online e em revistas impressas se deu em nível global.

\subsubsection{Entrevista com a CEO da empresa}

Ao perguntar qual o potencial do Brasil no mercado de Hospitalidade e Branding e porque a escolha da vinda para o país, Andrea afirmou com conviç̧ão que o potencial do país no Mercado de hospitalidade tem diferentes aspectos, alguns tristes, porém são a realidade em relação a crise atual que o país se encontra. "A crise faz com que a moeda perca valor e fica muito mais barato para turistas visitarem e trazer dinheiro de fora". Mas na perspectiva do branding ela elogia a energia positiva e vibrante da marca propriamente dita do Brasil. "É diferente de vender a Holanda ou Áustria, o Brasil tem sua marca, assim como o estilo de vida, que enche os olhos dos empreendedores internacionais".

Em termos de ativações e branding, os profissionais da área podem utilizar de diferentes maneiras os atributos e a personalidade que o país possui como o mar, a amizade, receptividade, o samba, o calor humano do carnaval, cores, as praias tropicais. $E$ isso que está por trás do branding, você cria um mundo para o consumidor experimentar e adentrar.

A pergunta seguinte foi como a competitividade na era digital influência na demanda dos clientes. Ela respondeu que nos dias atuais não existe nenhuma possibilidade de se ter uma marca bem sucedida e uma boa repercussão das ativações sem ter uma presença sólida online. Os sites e as mídias sociais mudaram a lógica dos cartões de visita e da primeira impressão que se tem de uma pessoa ou empresa. É o lugar onde as pessoas consultam antes de efetivamente comprar o produto/serviço. 
Isso se conecta com a questão anterior em relação a criar uma abordagem holística para o cliente quando se trabalha com ativações e branding. "Você pode produzir um belo evento, por exemplo, mas se tiver um site que deixa a desejar ou mídias sócias com imagens que não inspiram e motivam, aí é um caso perdido".

$\mathrm{Na}$ terceira pergunta ela respondeu como associam as marcas dos clientes aos adjetivos pretendidos. "Cada projeto tem suas particularidades e demandas diferentes, mas damos muita importância à criação de conteúdo valioso e ao storytelling". Através da produção de vídeos, que contam histórias da marca e da experiência propriamente dita, são comunicadas ao público e isso se torna um fator chave para o sucesso da marca.

A quarta pergunta foi direcionada a entender qual o objetivo da Tropicalisto quando desenvolve um evento para um cliente e ela respondeu que o propósito e essência da Tropicalisto é criar de fato um mundo de experiências que vai impactar emocionalmente e surpreender o cliente. Por exemplo durante o projeto da Casa Fat Radish, uma vez que o cliente passava pelas portas da casa, a intenção foi fazer com eles entrassem em um mundo mágico paralelo com música, ambientação, decoração, comida e iluminação que mais uma vez a experiência holística pudesse ser completa. Resumindo, o propósito é surpreender emocionalmente os clientes e evocar de fato emoções nos clientes potenciais em relação à marca. Não é somente para ser um evento que o público goste, mas sim impactar a memória desse indivíduo ao associar os momentos incríveis que ele passou com as marcas presentes.

Em relação às maiores barreiras encontradas ao longo dos projetos, Andrea afirmou que para proporcionar o tipo de ativação que a Tropicalisto se propões a fazer, existem muitas dificuldades ao longo dos projetos. Os mais comuns são questões operacionais na garantia de melhores fornecedores no caso de ter um restaurante envolvido. "Prazos são sempre questões de preocupação quando se tem uma experiência complexa para ser entregue para um cliente exigente. Principalmente pelas diferenças culturais entre brasileiros e europeus em relação à entrega dentro do prazo estabelecido.

A maior dificuldade, segundo ela, é o alinhamento dos objetivos estratégicos de comunicação da marca com a captação das mensagens e associações por parte dos consumidores. "Dependendo do público, os

\footnotetext{
${ }^{6}$ Storytelling é uma palavra em inglês, que está relacionada com uma narrativa e significa a capacidade de contar histórias relevantes.
} 
consumidores buscam puramente um entretenimento escapista e não vivem as experiências oferecidas de acordo com a expectativa das marcas patrocinadoras". E concluiu que existem muitos elementos de risco dentro de produção de eventos, desde da garantia de guardanapos de pano limpos até a integridade de um chef internacional depois de uma noite no Rio de Janeiro. No final das contas, para ela, todos esses elementos contam na percepção do consumidor em relação à marca.

Levando em consideração o ambiente em constante mudança, os consumidores exigentes mais informados, a valorização das estratégias de mídias BTL e as formas de patrocínio, surge o questionamento acerca da interpretação adequada dos consumidores ao se depararem com a comunicação das marcas que promovem eventos de hospitalidade e seus valores. 


\section{Resultados}

As casas olímpicas são os eventos de hospitalidade que mais se aproximam do evento mencionado no caso anteriormente descrito. Em ambas as situações a cidade estava sob condições semelhantes como a realização de competições esportivas, muitos turistas pelas ruas e consumidores buscando entretenimento dentre as diversas opções de eventos realizados por diferentes empresas. Tanto a Casa Fat Radish quanto as Casas Olímpicas que serão mencionadas a seguir, foram exemplos de casas que tiveram marcas atuando como patrocinadoras. Nesse contexto, pode-se considerar também o próprio país sede da casa como sendo uma marca.

\subsection{Entrevistas}

T.A.S. de 28 anos visitou as casas da Holanda, Bulgária e França, em busca de festas. Destacou como ponto forte a infraestrutura da Casa Holanda e como ponto fraco os altos preços das bebidas. No dia da visita, o momento mais marcante para ele foi a cerimônia da entrega de medalhas para os atletas.

$\mathrm{Na}$ Casa da Bulgária tinha hora para entrar e a alimentação era através de foodtrucks. Já na da França estavam promovendo somente festas. "O espaço estava bem apertado pela quantidade de pessoas, isso foi um ponto fraco". Disse também que poderia ter comida francesa e na Casa da Holanda deveriam explorar mais questões culturais. Após o evento mudou a percepção quanto a força da cerveja Heineken na Holanda. "Bebo com frequência essa cerveja, mas não associo diretamente ao país". As associações que faz à Heineken são: Holanda, Qualidade e Festa. Classifica as experiências como afetivas por conta do clima olímpico e da cerimônia que despertou emoção ao ver os atletas e holandeses comemorando. 
M.B de 23 anos nem entrou na Casa da Suíça por conta das filas. Foi para casa da Holanda com a família em uma noite de festa. Comeu hambúrguer, viram jogos e beberam cerveja. Destacou a ambiência e alto astral como pontos fortes. Percebeu que os holandeses não estavam satisfeitos com a quantidade de brasileiros no local. Ela gostaria que tivesse facilidade de entrar e acesso ao bar para tornar a visita mais agradável. "As filas dificultam a experiência como um todo".

O momento que marcou sua noite foi a cerimonia de distribuição de medalhas e as comemorações dos holandeses. "Nessa hora deu para ver muito bem a diferença cultural simplesmente pela dança e músicas que tocaram". Por ter nacionalidade holandesa, a casa não mudou sua percepção em relação ao país. Elogiou a estrutura do merchandising da Heineken e as associações que faz com a marca são: Jovem, Inovadora e Experiências. Classifica as experiências como afetivas pelo astral do lugar e por estar com a família, fazendo com que essa lembrança fique em sua memória.

C.B foi selecionado por uma empresa para trabalhar na casa olímpica da Nike, no Itanhangá. A casa era para atletas, convidados e formadores de opinião. Um local de "fuga" das grandes atrações olímpicas para as massas, saindo das rotinas de entrevistas. O local tinha como intenção mostrar os produtos da marca para os convidados e uma atenção especial para os atletas. Esses ganhavam produtos, personalizavam camisas, tênis, ganhavam kits, tinham direito a comida liberada e tinham acesso a um lounge.

Havia uma área especialmente voltada para as mulheres, segundo o posicionamento da marca voltado par ao público feminino. Podiam experimentar roupas, massagem, spa. Como a localidade é próxima a um campo de golfe, os convidados podiam praticar o esporte. No complexo havia uma sala de mídia nacional e internacional para entrevistas marcadas com antecedência e mais reservadas, ao contrário de sua concorrente, Adidas, que não investiu em uma casa como essa.

Ele destaca a hospitalidade como um todo. A receptividade dos funcionários, a ideia em si e a liberdade que os atletas tinham em decidir o que fazer, não eram sufocados com entrevistas ou fãs. Como ponto negativo citou que nem todas as atividades estavam disponíveis para todos. Mesmo dentro de um ambiente seletivo e reservado haviam espaços reservados somente para atletas. C. destaca que gostaria de ter tirado e publicado algumas fotos nas mídias sociais, porém como funcionário, não podia divulgar o que acontecia dentro do espaço. O seu momento mais marcante foi no meio das olimpíadas, 
quando abriram o camarote da Nike no Estádio do Engenhão para os funcionários para ver o atletismo.

Mudou sua percepção completamente pela marca. Antes do evento tinha preferência pela marca concorrente, porém depois, começou a acessar os canais de comunicação da marca como Youtube, compra produtos da marca e tem muito mais informação sobre. "Ganharam um consumidor". As associações que faz a Nike são: Diferencial, Ousadia e Estilo. Classifica as experiências como afetivas por conta do sentimento de pertencimento proporcionado pela interação entre atletas, funcionários e marca.

L.F.M.B de 22 foi na casa da Alemanha e da Dinamarca, ambas no Leblon. Gostou bastante da Alemanha por conta da quantidade de pessoas presentes na noite que foi e uma ambiência com bom astral por ser na praia. Tinham atividades relacionadas com esportes olímpicos como basquete e totó. Ponto fraco foi a cerveja cara, filas para entrar e comprar. Sugeriu uma maior interação com a cultura especifica do país sede da casa para tornar a experiência mais completa. "Achei que ia ter mais acesso à cultura alemã". Seu momento mais marcante foi a atividade de um quadro interativo na casa da Dinamarca, que a partir da escrita em um quadro, aparecia em uma tela grande para outras pessoas verem. Associa a Alemanha com: Cerveja, Mulheres loiras e Oktober Fest. Classifica as experiências como comportamentais pelas atividades interativas e sensoriais pelas músicas que tocaram.

A.N, 24 anos, foi na Casa do Japão na Cidade das Artes, Barra da Tijuca. Logo que chegou, gostou do local por ser uma construção grandiosa. A casa oferecia exposições de bonecas japonesas, de itens com o tema Tokyo 2020 (onde as próximas olimpíadas serão realizadas), pratos típicos da cultura japonesa, carro sustentável da marca japona Toyota, quadro de recados para os atletas, mapa do país, quadro de fotos dos atletas, além de projeções, roupas temáticas, atividade de caligrafia japonesa, degustação de bebidas e shows de música. Como ponto forte citou a quantidade de atividades e informações fornecidas pela casa. Como ponto fraco lembrou do vento intenso na parte externa, por ser um local descampado. "Foram tantas as experiências que acho que não faltou nada", respondeu. O momento mais marcante para ela foi a atividade de caligrafia, por estudar design. A.N só confirmou a percepção que tinha sobre os japoneses e os associa com: Educação, Organização e Tecnologia. Classifica as experiências como sensoriais e comportamentais.

L.P de 22 frequentou a casa da Suíça na Lagoa e da Jamaica, na Gávea. Dentre as diversas atividades da casa da Suíça, de entrada gratuita, destacou a 
patinação no gelo e pequenos restaurantes com comidas típicas do país. A da Jamaica era mais focada em festas. "Cada casa tentou retratar um pouco da própria cultura, umas o fizeram melhor, outras, pior". Destacou a localização da casa da Suíça ao ar livre, porém faltou coesão entre as atividades. "Parecia um parque para crianças, ainda mais por conta das filas".

Segundo o entrevistado podiam ter montado uma estrutura panorâmica para mostrar um pouco da história e cultura de cada país. Fazer com que esses pontos fossem fatores para aumentar mais ainda a globalização e o turismo, além de contar um pouco das conquistas do esporte do país.

A festa da casa da Jamaica foi o momento mais marcante para L.P. Todos estavam no clima olímpico. Associou o clima "ameno" da Lagoa com a personalidade dos suíços, considerada mais fria por ele. Por conta do espaço estar tão cheio nem conseguiu ver associação entre marcas e país. As associações que faz com Suíça são: Pontualidade, Seriedade e Frio. Classifica as experiências como comportamentais por conta das atividades propostas pela casa da Suíça.

T.T de 23 anos visitou a casa da Jamaica e trabalhou na casa da Suíça. Foi a uma festa na casa da Jamaica, pagando $\mathrm{R} \$ 60,00$ de entrada, que teve como atração o show do filho do Bob Marley e a comemoração do aniversário do atleta Usain Bolt. Na casa tinham guias informativos sobre a Jamaica, agencias oferecendo pacotes de viagens e turismo, um restaurante com comidas típicas e a ativação da cerveja jamaicana Red Stripe (vendida a $R \$ 15,00$ ). "Eu estava bebendo uma cerveja do país e ouvindo reggae, me senti na Jamaica".

T.T trabalhou como "Guest Relations" durante as Olimpíadas e as Paraolimpíadas no Baixo Suíça, como era chamada a Casa Suíça. Por a entrada ser gratuita ele destacou: "Isso faz com que o ambiente seja mais democrático". Além de receber atletas e convidados, a casa tinha diversas atividades oferecidas por empresas suíças. Tinham ativações como uma pista de corrida da Omega que era patrocinadora oficial das Olimpíadas 2016; um museu da Nestlé; degustação de vinho suíço; restaurante de comida típica; patinação e simulador de neve (destaca a atividade como grande ponto forte em um ambiente gratuito por conta das diferenças climáticas entre Brasil e Suíça), "essa experiência fez com que pessoas que não tem condições financeiras de ir até a neve, possam entrar em contato com a atividade e desenvolver percepções sobre o país". Para ele o ponto fraco eram as longas filas para a entrada.

Após ter trabalhado na casa mudou completamente sua percepção em relação ao país. "Aprendi muito sobre a cultura da Suíça e suas divisões 
territoriais". Ele conta que os organizadores e as marcas envolvidas fizeram uma apresentação antes da abertura para treinar os funcionários em como representar a Suíça. Associa o país com: Relógio, Chocolate e Montanha.

Classifica as experiências como afetivas na Casa da Jamaica. "Eu estava ouvindo as músicas do Bob Marley, cantadas por seu filho e fazendo parte do aniversário de um atleta tão emblemático e querido como o Bolt". E na da Suíça comportamentais e sensoriais por conta das tantas atividades interativas

M.P de 29 anos, visitou a Casa Dinamarca. Gostou das exibições interativas e experiências. Destacou como ponto forte os DJs e shows, além de bicicletas que estavam em exposição e uma casa LEGO (marca dinamarquesa). Por ser gratuita, o tempo de permanência era de no máximo vinte minutos, mediante a um cadastro no local. Ela sugeriu que informações sobre a história da marca LEGO fossem fornecidas para os visitantes. O mais marcante para ela foi a maquete do Rio de Janeiro construída com LEGO. Ela afirma que mudou a percepção quanto ao país: "Eu não fazia ideia que a marca dos brinquedos que eu brincava mais nova era dinamarquesa". Associa a marca LEGO com: Criança, Construir e Colorido. Classifica as experiências como afetivas por se lembrar da infância.

L.F, 26, visitou com o namorado a Casa da Colômbia, porém não foi uma experiência surpreendente. Com entrada gratuita, as atividades na parte externa eram shows e uma cafeteria do conhecido café colombiano Juan Valdez, o qual ela nunca tinha experimentado. Na parte interna haviam ativações de produtos típicos colombianos, arte, informações sobre turismo e a venda das tradicionais rosas do país. Além da circulação livre, a imprensa podia entrar na casa para filmar e entrevistar visitantes. Como ponto franco citou a falta da culinária da região. Não mudou sua percepção em relação ao país e suas marcas. Associa a Colômbia com: Pablo Escobar, Dança e Café. Classifica as experiências como sensoriais por ter bebido café.

S.G de 25 anos foi na Casa de Portugal que na verdade era uma embarcação chamada Sagres na qual retratava uma caravela da época do descobrimento do Brasil e ficou localizada na zona portuária do Rio de Janeiro. A primeira impressão foi negativa: fila de $2 \mathrm{~h}$ para entrar. "Eu já entrei no barco com vontade de ir para casa". A casa contava com marinheiros portugueses que recebiam os visitantes. Segundo ele não valeu a pena esperar para entrar no barco. Não tiveram pontos fortes. Poderiam ter atividades interativas e notícias sobre os atletas do país. Não teve nenhuma ativação de marcas. Classifica como sensorial somente pelo fato de ter olhado o interior bonito do barco. 
G.R.A. 22, visitou a Casa da Suíça. Gostou muito da localização (Lagoa Rodrigo de Freitas), da área de alimentação e da pista de corrida. Enfrentou uma pequena fila pois foi na parte da manhã. Para ele o momento mais marcante foi quando comeu uma comida típica e elogiou o sabor. Enquanto estava lá, transmitiram o jogo de futebol feminino Brasil x Suíça. Elogiou a infraestrutura e a vista panorâmica. Gostaria que estivesse menos cheio para aproveitar todas as atividades sem filas. Aprendeu muitas informações no stand dos canivetes da Vitorinox e comprou um. Associa a marca com: Qualidade, Multifuncional e Suíça. Classifica as experiências como sensoriais pois as atividades e a comida mexeram com os seus sentidos.

R.B.P.E. de 30 anos, frequentou por dois dias a Casa da Áustria. Disse que na parte interna tinha um salão com mesas cumpridas para jantares, uma pista de dança e televisores transmitindo os esportes. Durante o dia, atletas e representantes da comissão olímpica podiam relaxar e pedir comida ou bebida para os funcionários com trajes temáticos. A casa contou com o patrocínio da cerveja austríaca Stiegel. Ele conta que o forte da casa era a culinária típica (principalmente os pães produzidos lá mesmo) e a banda ao vivo na parte externa. "Foi muito animado aquele clima austríaco com comida e música da região". Estava muito quente na parte externa, poderiam ter instalado um toldo ou ventiladores grandes. O momento mais marcante para ele foi a banda ao vivo tocando instrumentos como violino, trompete e contrabaixo ao beber uma cerveja austríaca. "Mudei minha percepção em relação ao país e o que tem a oferecer como cultura, culinária e música". Associa o país com: Cerveja, Bigode e Pães. Classifica a experiência como sensorial por causa da música, comida e bebida.

M.N.O de 24 anos, visitou a Casa da República Tcheca, gratuita para entrar. Na Casa Tcheca, como era denominada, havia exibição dos jogos em um lounge com cadeiras personalizadas, quadros com informações sobre o país, artigos de design, venda de cerveja típica e sessões de autógrafos. Logo que entrou se deparou com uma instalação artística de um designer tcheco na qual pernas se movimentavam no teto como se tivessem correndo no ar. "Isso foi o momento mais marcante pois achei a ideia diferente". Para ela, o ponto fraco era a fila para comprar cerveja e reclamou da falta de atividades interativas. Não mudou a percepção em nenhum aspecto. Associa a República Tcheca com: Cerveja, frio e mulheres bonitas. Classifica a experiência como sensorial somente pela visão. 
R.L.J. de 26 anos visitou a casa da África na Barra da Tijuca. "A única coisa interessante era que todos os países do continente estavam sendo representados no local", conta ela. A casa contava com painéis mostrando a logo dos comitês olímpicos de cada país, exposições de bonecas e artefatos religiosos africanos, roupas típicas, stand de cabelereiro e decoração típica. "O ponto fraco foi que o espaço era muito pequeno para os países mostrarem sua cultura", afirmou ela acrescentando que parecia que os funcionários não estavam satisfeitos. Como não viu nenhuma marca, R. associa o continente com: Felicidade, Diversidade e Povo batalhador. Classifica as experiências como sensoriais por olhar os artefatos da cultura africana.

J.Y. de 30 anos, participou da produção da Casa Brasil, localizada na zona portuária do Rio. Segundo ele o espaço foi uma estratégia de promoção do país durante as Olimpíadas e Paraolimpíadas 2016. Tanto o turista nacional quanto o internacional tiveram acesso à riqueza e diversidade cultural de uma forma viva e interativa através de exposições e informações, além de experimentar esportes paraolímpicos como o basquete com cadeira de rodas. O propósito da casa era de expor cultura, diversidade e mostrar para quem vem de fora, o potencial do Brasil em fazer negócios através de encontros de investidores em um armazém do Pier Mauá. Com ativações do Banco do Brasil, da Caixa Econômica Federal e palestras, a coordenação do projeto foi feita pela Apex (Agência Brasileira de Promoção de Exportações e Investimentos) em conjunto com alguns Ministérios. A parte mais marcante para $\mathrm{J}$. foi o encontro de uma tribo indígena com os visitantes. O ponto forte para ele foi a localização e a cenografia da instalação. J. sentiu falta de bons pratos típicos, mas reconhece que não era esse o propósito da casa. Ele notou mudanças no comportamento dos próprios visitantes brasileiros que ficaram surpresos com a qualidade da produção e ouviu de uma mulher: "nem parece que é do Brasil". Depois da casa passou a associar o país com: Diversidade, Cultura e Musicalidade. Classifica as experiências como afetivas por conta da emoção evocada pela casa. 


\section{Conclusões}

Serão expostos nesta seção o levantamento dos resultados das entrevistas exploratórias, a conclusão do trabalho e sugestões de ações para empresas que atuam no setor de eventos de hospitalidade, como a Tropicalisto, poderem mitigar as dificuldades existentes e possíveis ameaças.

Ao ir a campo com a problemática, foi identificado que a percepção do público era muito diversa. Por isso, não é possível tirar conclusões, afinal a pesquisa foi de cunho exploratório, porém ao analisar o caso e as entrevistas, parece que as ações de patrocínio, ativação de marca, branding e experiência de marca são efetivas na comunicação de conteúdo proposto pelas marcas. As evidências de que essas ações memoráveis contribuem para aumentar o valor da marca, são claras. Mas o questionamento que surge é se também contribuem para o aumento de vendas e parcela de mercado. Como essas iniciativas buscam aproximar e fortalecer o relacionamento duradouro com o consumidor, essas dúvidas podem ser respondidas a longo prazo, quando o mesmo estiver em um nível de lealdade maior com a marca.

Mostrou-se através do caso da Tropicalisto, nesse setor, que projetos de curto prazo como as pop-ups reduzem custos de aluguel por longos períodos. Mesmo tendo data para começar e terminar, os números de rotatividade de pessoas nos eventos e interação nas mídias sociais mostram a rápida repercussão do marketing nos canais de comunicação. Além de redução de custos, esse tipo de estratégia é um bom termômetro para avaliar se vale a pena investir em outras ações mais duradouras.

Foram indicados, através das entrevistas, alguns pontos recorrentes como as longas esperas em filas para entrar nas casas ou ter acesso a comida e bebida, as quais afetam negativamente a experiência do consumidor; a menção da presença da cultura de cada país nas casas, em alguns exemplos a falta desse fator, em outros, como ponto positivo e a classificação desse tipo de ação como sendo predominantemente sensorial, por conta das atrações e atividades oferecidas pelos eventos.

O caso sugere que as diferenças culturais entre o Brasil e outros países podem ser considerados um risco para projetos que envolvem marcas de grande 
porte. Porém, as entrevistas indicam que o fator cultural na perspectiva do consumidor é um atrativo. A produção de ações estrangeiras, como as casas olímpicas, enriquece a experiência e aumenta a curiosidade do público nacional.

Grande parte dos exemplos mencionados nesse trabalho conseguiram promover experiências de marca completas, ou quase completas, de acordo com Oliver (1997) e Brakus et al (2009). As casas ofereceram ativações como forma de conexão entre o consumidor e as marcas patrocinadoras, experiências memoráveis para despertar encantamento, e a própria hospitalidade, visando o bem-estar e a satisfação dos visitantes.

Para que os valores da marca sejam postos em evidência nesse tipo de ação, as dimensões sensoriais, comportamentais, intelectuais e afetivas da experiência são indispensáveis e compõem os atributos do evento de forma holística. As marcas devem estimular as associações na mente dos consumidores de maneira forte, favorável e exclusiva para que a construção do valor da marca seja feita (Aaker, 1991). As ações de experiência nos eventos de hospitalidade contribuem para que essas associações sejam feitas mais facilmente.

Algumas dessas ações de patrocínio são exclusivas e restringem o acesso a um público com maior poder aquisitivo. Esse fato é inevitável em certos tipos de evento, pois representa o posicionamento da marca. Porém ao permitir o acesso a públicos diversos, como foi o caso das casas olímpicas com entrada gratuita, a ação se torna mais democrática e sugere um maior alcance dos valores da marca. Levando isso em consideração, as entrevistas e a análise do caso apontam caminhos distintos de estratégia, dependendo do objetivo. 


\section{Referências}

AMPRO, Associação de Marketing Promocional. Disponível em: http://www.ampro.com.br/ampro/mkt_promocional/

AAKER, David A.. Brand Equity: gerenciando o valor da marca. Trad. André Andrade. São Paulo: Negócio, 1996.

ADITYA, Blog-Off II Entry: Impact of recession on Approaches to Brand Promotion http://www.communitymarketing.typepad.com/my_weblog/2009/12/impactof- recession-on-approaches-to-brand-promotion.html

BAYNAST, Lendrevie e EMPRIN, C. Publicitor: $360^{\circ}$ Communication On Line and Off Line. Paris, 2008

BRAKUS, J. Josko, Bernd H. SCHMITT, and ZARANTONELLO. "Experiential Attributes and Consumer Judgments," in Handbook on Brand and Experience Management, Bernd H. Schmitt and David Rogers, eds. Northampton, MA: Edward Elgar. 2008

BRAKUS, J. J., SCHMITT, B. H., \& ZARANTONELLO, L. Brand Experience: What is It? How is It Measured? Does It Affect Loyalty?. J. Mark., 73(3), 5268. http://dx.doi.org/10.1509/jmkg.73.3.52 - 2009.

CABIN, P., DORTIER, J.F., \& RUANO-BORBALAN, J.C. La Communication État des Savoirs. Auxerre: Sciences Humaines Éditions. (1998).

de CHERNATONY, L. and DALL'OLMO Riley, F. Defining a Brand: Beyond the Literature with Experts' Interpretations, Journal of Marketing Management, Vol. 14, No. 5, pp. 417-443 - ANBAR citation of excellence award, 1998

COBRA, Marcos. Administração de marketing. 2. Ed. São Paulo: Atlas, 1992.

CRUZ, Tadeu. Gerência do Conhecimento. São Paulo:Cobra, 2002.

ESCOBAR, Mauricio Nogueira. Patrocínio Esportivo e seus Efeitos sobre o Valor da Marca: Um Estudo Exploratório no Brasil. São Paulo., 2002. (Dissertação de Mestrado apresentada no Curso de Mestrado em Administração de Empresas, Área de Concentração: Mercadologia) : EAESP-FGV

FISHBEIN, M., \& AJZEN, I. Predicting and changing behavior: The reasoned action approach. New York: Psychology Press (Taylor \& Francis), 2009

GIL, Antonio Carlos. Métodos e técnicas de pesquisa social - 6. ed. - São Paulo : Atlas, 2008.

GUIMARÃES, Ricardo. Branding: Uma nova filosofia de gestão, IN: Revista ESPM, São Paulo: V. 10, ano 9, p. 86 - 103, março/ abril 2003. 
KAPFERER, Jean-Noël. As Marcas. Porto Alegre: Bookman, 2004.

LENDREVIE, J., Baynast (de), A., \& Emprin, C. Publicitor: La communication 360o - Techniques off line et on line (7ème edition). Livres en Or, Dunod. (2008).

LEVINSON, S. C.. Optimizing person reference - perspectives from usage on Rossel Island. In N. Enfield, \& T. Stivers (Eds.), Person reference in interaction: Linguistic, cultural, and social perspectives (pp. 29-72), 2007.

MACEDO-SOARES, T. Diana L.v.A. de ; MAYRINK, E. F. ; CAVALIERI, A.Strategic Fit of Project Management: The case of Eletronuclear. - - Journal of Global Business and Technology, v. 5, p. 1-14 - 2009

MEENAGHAN, T. Understanding sponsorship effects. Psychology \& Marketing, 18(2), 95-122, 2001.

MELO NETO, Francisco Paulo de. "Marketing de Patrocínio". Rio de janeiro, Ed. Sprint, 2000.

OLIVER, Richard L. Satisfaction: A Behavioral Perspective on the Consumer, New York, NY: McGraw-Hill, 1997.

POZZI, L., OLIVEIRA, M. Patrocine o Evento Certo. Mercado Global. São Paulo, n.99, p.13.15. 1996.

PAVITT, Jane. (org). Brand New. London. Priceton University Press. 2003.

PINE, B. Joseph II and GILMORE, James, "Welcome to the Experience Economy," Harvard Business Review, July 1, 1998

PINHO, J. B. O Poder Das Marcas. São Paulo: Summus,1996.

PORTER, Michael. Vantagem competitiva: criando e sustentando um desempenho superior. Rio de Janeiro: Elsevier, 1989.

POZZI, Luis Fernando. "A Grande Jogada: as Bases do Marketing Esportivo". Ed. Globo, 1998.

RODRIGUES, Delamo. Um Breve Panorama do Branding. IN: Anais do Congresso Brasileiro de Pesquisa e Desenvolvimento e Design. P\&D, Paraná. 2006

SANDLER, D.M.; SHANI D. Olympic sponsorships prove reliable in targeting ethnics: Marketing News, January 18, 1989, pp.8,15.

SCHMITT, Bernd H. Marketing Experimental. São Paulo: Nobel, 2001.

SHIMP, T. A. Propaganda e promoção. 5. ed. Porto Alegre: Bookman, 2002.

SOLOMON, M. O comportamento do consumidor. 5. ed. Porto Alegre: Bookman, 2002.

WINTENBERRY, Group. www.winterberrygroup.com. 2006. 